\title{
Isolation of Lumpy skin disease virus form naturally infected cattle previously vaccinated with live attenuated sheep poxvirus vaccine
}

\author{
S. M. Tamam* \\ Virology Department Faculty of Veterinary Medicine Beni Suef University
}

\begin{abstract}
Lumpy skin disease virus (LSDV) was isolated, from naturally infected cattle that have a history of previous vaccination with live attenuated sheep pox virus (SPV) vaccine. The virus was isolated on chorio-allantoic membrane (CAM) of specific pathogen free (SPF) embryonated chicken eggs (ECE) and identified by agar gel precipitation test (AGPT) and neutralization test using specific hyperimmune serum against LSDV and SPV. Characteristic intracytoplasmic inclusion bodies was detected in trypsenized cell of infected CAM stained with H\&E. Laboratory studies for characterization of isolated LSDV revealed that it was stable at a wide range of $\mathrm{pH}$, but it was inactivated by exposure to $56{ }^{\circ} \mathrm{C}$ for 15 minutes. Treatment of isolated LSDV with lipid solvents $(20 \%$ ethyle ether and chloroform) reduced the virus titer 3.2 and $4.4 \mathrm{log}$ respectively after $24 \mathrm{hrs}$ at $4{ }^{\circ} \mathrm{C}$.On cross neutralization test complete neutralization of isolated LSDV was obtained with both reference LSDV and SPV antisera. Cattle vaccinated with live attenuated SPV vaccine under experimental condition found to be protected against natural field infection with LSDV.
\end{abstract}

Lumpy skin disease (LSD) is a skin disease of cattle caused by a strain of genus Capripox virus which causes an acute, subacute or in apparent infection in cattle of all ages and breeds. The disease is characterized by fever, skin nodules, and necrotic plaques in mucosa, pneumonia and lymphadenopathy. The severity of the disease varies considerably between breeds and strains of cattle (Davies, 1991).

The disease causes considerable economic losses due to emaciation, damage of hides, infertility in males and females, mastitis, loss of milk production with morbidity up to $100 \%$ in natural outbreaks and mortality rate rarely exceeds 5\% (Barnard et al., 1994). The disease is listed in the office international des Epizooties "List A" which identifies diseases with the potential for rapid spread and severe economic losses (Irons et al., 2005). Field observations and supporting evidence indicates that the disease is transmitted by biting flies. There are also indications of transmission in the absence of insect vectors, whereas contact transmission between animals is extremely inefficient (Carn and Kitching, 1995).

\footnotetext{
* Corresponding author. Tel.: +20 124683681; fax: +20822327982 .

E-mail address: smtamam@yahoo.com (S. M. Tamam)
}

In Egypt the disease was investigated for the first time by (Ali et al., 1990) where the disease was introduced as a result of importation of infected Somalin cattle (Fayed et al., 1988). In countries where the disease is enzootic, prophylactic immunization is the only satisfactory method for controlling it.

Control of LSDV in Egypt depends on prophylactic vaccination programs using live attenuated cell culture adapted sheep pox virus vaccine (Michael et al., 1994). This work aims to clarify the reasons of appearance of LSDV among cattle previously vaccinated with live attenuated SPV vaccine.

\section{Materials and Methods}

Virus strain. (i) Ismalian strain of LSDV (Reference strain) of a titer $10^{5.5} \mathrm{TCID}_{50}$ was obtained from Virology Department, Animal Health Research Institute, Dokki, Giza, Egypt.

(ii) Live attenuated SPV vaccine of a titer $10^{5.5}$ $\mathrm{TCID}_{50}$ was obtained from Serum and Vaccine Research Institute, Abbasia, Cairo, Egypt and used in cross neutralization test.

Samples: Intracutaneous skin nodules were collected by biopsy from naturally infected cattle suspected to be infected with LSDV infection (Fig.1) with a history of previous vaccination with live attenuated SPV vaccines located at different areas in Beni-Suef Governorate. 
Collected samples were ground in sterile PBS and $10 \%$ suspension was prepared in sterile PBS containing antibiotics. The obtained supernatant was stored at $-20{ }^{\circ} \mathrm{C}$ until used for virus isolation. Specific pathogen free (SPF) Embryonated chicken eggs (ECE). SPF ECE were purchased from Koum Oshim, farm, Fayoum, Egypt and used for virus isolation and neutralization test.

Commercial ECE. 11-13 days old embryos were purchased from El-Azzab poultry production farm, Fayoum, Egypt and used for virus titration. ECE were inoculated via CAM rout (11-13 days old embryos) and incubated at $35{ }^{\circ} \mathrm{C}$ and $70 \%$ humidity for 5 days post inoculation.

Sera and antisera. Reference lumpy skin disease antisera were obtained from Virology Department, Animal Health Research Institute, Dokki, Giza. Reference sheep pox virus antisera were obtained from Virology Department, Fac, Vet, Med. Beni-Suef University, Egypt. Serum samples were collected from naturally infected cattle 1-2 months post infection.

Cattle. Thirty cattle of different breeds aged from 6 months to 5 years old, their sera proved to be free from LSDV antibodies by AGPT located at private farm at Beni-Suef Governorate are used to evaluate protection afforded by live attenuated SPV vaccine.

Virus Isolation. Lumpy skin disease virus was isolated from collected samples on CAM of ECE according to (House et al., 1990). The infectivity titer of isolated virus was determined and egg infective dose $50 \quad\left(\mathrm{EID}_{50}\right)$ were calculated according to (Reed and Muench, 1938).

A gar gel precipitation test (AGPT). It was applied according to (Davies 1981).

Trypsenized membrane test (TMT). It was applied according to (Madbouly et al., 1996) and used for detection of intracytoplasmic inclusion bodies on infected CAM.

Neutralization and cross neutralization tests. Tests were applied according to (Pandey and Singh, 1970).

Characterization of isolated LSDV. Isolated strain of LSDV was tested for pH stability, ether and chloroform sensitivity as well as heat stability. pH stability was performed according to (Charles and Stuart, 1947), ether and chloroform sensitivity were performed according to (Andrewes and Horstmann, 1949). Heat stability was conducted according to (Benton et al., 1967).

Experimental design. Thirty cattle of different breeds and ages located at private farm at Beni-
Suef Governorate were vaccinated with live attenuated SPV vaccine (the vial is reconstituted with $100 \mathrm{ml}$ saline and $1 \mathrm{ml}$ of the vaccine is inoculated I/D in tail fold). Vaccinated cattle were kept in separate hygienic place for one month and sera were collected and examined by AGPT. After one month vaccinated cattle were exposed to natural infection by keeping them in contact with naturally infected cattle and kept under observation for two months.

\section{Results}

Isolation of lumpy skin disease virus on CAM of ECE. LSDV was isolated on CAM of ECE and produced characteristic pock lesion (Fig. 2).

Identification of isolated LSDV. The LSDV antigens in infected CAM were detected by AGPT using reference LSDV and SPV antisersa. Also characteristic intracytoplasmic inclusion bodies were detected by TMT on infected cells of CAM (Fig. 3). The isolated virus was identified also by neutralization test (Table 1, 2)

\section{Characterization of isolated LSDV.}

Cross neutralization test for locally isolated LSDV.

It was applied on SPF-ECE using reference LSDV antisera and reference SPV antisera (Table 6).

\section{Vaccination trial.}

Vaccinated cattle showed precipitating antibodies by AGPT one month after vaccination. Clinical observation of these vaccinated cattle revealed no apparent clinical signs of LSDV for two months after exposure to natural field infection.

\section{Discussion}

Lumpy skin disease (LSDV) is a serious disease of cattle caused by a single strain of Capripox virus. It is characterized by nodular cutaneous eruptions, lymphadentis, and oedema in one or more limbs (Haig, 1957). In the present study LSDV was isolated from samples collected from naturally infected cattle (previously vaccinated with live attenuated SPV vaccine) by inoculation on CAM of SPF-ECE. Characteristic pock lesions were observed after $1^{\text {st }}$ passage and become clear after $3^{\text {rd }}$ passage (Fig. 2). This finding agrees with (Woods, 1988; House et al., 1990; Hassan et al., 1992) who successfully cultivated LSDV on CAM of ECE and detected the characteristic pock lesions. Isolated LSDV was identified by serological tests and TMT (Table 1). Clear precipitation lines were appeared in AGPT by using reference LSDV antisera, SPV antisera and positive sera collected from field 


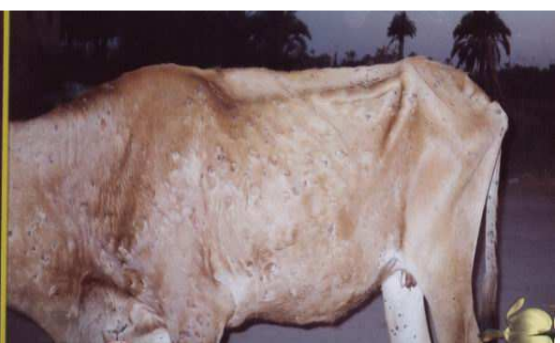

Fig. (1):Intracutaneous skin nodules on the body of naturally infected cattle.

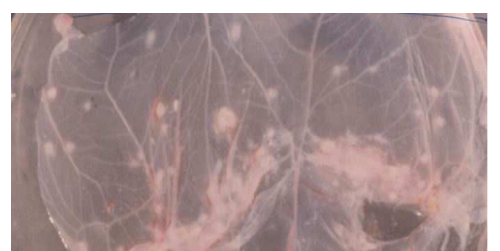

Fig. (2) : Characteristic pock lesions on infected CAM of ECE.

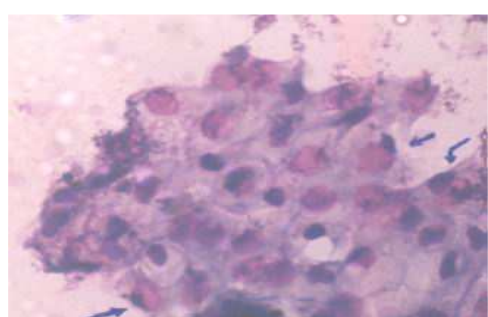

Fig. (3): Intracytoplamic inclusion bodies on infected cells of CAM.

Table (1): Identification of isolated LSDV in ECE.

\begin{tabular}{ll}
\hline Test & \multicolumn{1}{c}{ Results } \\
\hline AGPT & Clear lines of precipitation. \\
TMT & Interacytoplasmic inclusion bodies. \\
Neutralization test & Reduction of pock lesions. \\
\hline
\end{tabular}

Table (2): Neutralization index of isolated LSDV.

\begin{tabular}{lccc}
\multicolumn{1}{c}{ Antisera } & $\begin{array}{c}\text { Virus titer } \\
\left(\log _{\mathbf{1 0}} \mathbf{E I D}_{\mathbf{5 0}} / \mathbf{m l}\right)\end{array}$ & $\begin{array}{c}\text { Titer with } \\
\text { 4NU Abs }\end{array}$ & $\begin{array}{c}\text { Neutralization } \\
\text { index }\end{array}$ \\
\hline Reference LSDV antisera & 6.5 & 3.3 & 3.2 \\
Reference SPV antisera. & 6.5 & 3.3 & 3.2 \\
Positive sera of infected cattle & 6.5 & 3 & 3.5 \\
\hline
\end{tabular}

Table (3): Effect of pH on the infectivity of isolated LSDV.

\begin{tabular}{ccccccc}
\hline pH & $\begin{array}{c}\text { Before } \\
\text { treatment }\end{array}$ & $\mathbf{3}$ & $\mathbf{5}$ & $\mathbf{7 . 2}$ & $\mathbf{9}$ & $\mathbf{1 1}$ \\
\hline $\begin{array}{c}\text { Virus titer log 10 } \\
\text { EID }_{\mathbf{5 0}} / \mathbf{m l}\end{array}$ & 6.5 & 5.5 & 5.7 & 6.5 & 5.7 & 5.5 \\
\hline
\end{tabular}

Table (4): Effect of heating at $56{ }^{\circ} \mathrm{C}$ on the infectivity of isolated LSDV.

\begin{tabular}{|c|c|c|}
\hline Time of exposure & $\begin{array}{c}\text { Treated virus } \\
\log 10 \mathrm{EID}_{50} / \mathrm{ml}\end{array}$ & $\begin{array}{c}\text { Control virus } \\
\log 10 \mathrm{EID}_{50} / \mathrm{ml}\end{array}$ \\
\hline $5 \mathrm{~min}$ & 4.3 & 6.5 \\
\hline $10 \mathrm{~min}$ & 2.1 & 6.5 \\
\hline $15 \mathrm{~min}$ & 0 & 6.2 \\
\hline $30 \mathrm{~min}$ & 0 & 6.2 \\
\hline
\end{tabular}

Table (5): Effect of lipid solvent on the infectivity of isolated LSDV.

\begin{tabular}{cccc}
\hline Type of fat solvent & $\mathbf{2 0 \%}$ ether & Chloroform & Control virus \\
\hline Virus titer $\log \mathbf{1 0} \mathbf{E I D}_{\mathbf{5 0}} / \mathrm{ml}$ & 3.3 & 2.1 & 6.5 \\
\hline
\end{tabular}

Table (6): Cross neutralization test for locally isolated LSDV using 2 antisera.

\begin{tabular}{|c|c|c|c|c|c|}
\hline \multirow[t]{2}{*}{ Virus strain } & \multirow{2}{*}{$\begin{array}{c}\text { Original titer } \\
\log 10 \\
\text { EID }_{50} / \mathrm{ml}\end{array}$} & \multicolumn{2}{|c|}{$\begin{array}{l}\text { Treatment with } 4 \mathrm{NU} \text { of } \\
\text { Reference LSDV antisera }\end{array}$} & \multicolumn{2}{|c|}{$\begin{array}{c}\text { Treatment with } 4 \mathrm{NU} \text { of } \\
\text { SPV antisera }\end{array}$} \\
\hline & & Titer & NI & Titer & NI \\
\hline -Reference LSDV & 5.5 & 2.1 & 3.4 & 2.1 & 3.4 \\
\hline -Locally isolated strain of LSDV & 6.5 & 3.3 & 3.2 & 3.3 & 3.2 \\
\hline -Vaccinal strain of SPV & 5.5 & 2.1 & 3.4 & 2.1 & 3.4 \\
\hline
\end{tabular}


cases. Characteristic eosinophilic intracytoplasmic inclusion bodies were detected in trypsenized cell of infected CAM stained with H\&E (Fig.3). This result was in agreement with (Thomas and Mare, 1945) who observed intracytoplasmic inclusion bodies in histocytes and epithelial cells in the skin as well as in kidney cell culture infected with LSDV. The infectivity titer of isolated LSDV (6.5 $\log _{10}$ $\mathrm{EID}_{50} / \mathrm{ml}$ ) was reduced by using antiserum giving neutralization index $3.2,3.2$ and 3.5 with reference LSDV antisera, reference SPV antisera and positive sera collected from infected cattle respectively (Table 2). For characterization of isolated LSDV, $\mathrm{pH}$ stability indicated that the virus neither affected by acidic nor alkaline $\mathrm{pH}$ (Table 3). Heat inactivation studies revealed loss of $2.2 \log _{10} \mathrm{EID}_{50} / \mathrm{ml}$ in virus titer at $56^{\circ} \mathrm{C}$ for 5 min and complete inactivation after $15 \mathrm{~min}$ (Table 4). Fat solvent treatments revealed the liability of the isolated virus to such chemicals (Table5), indicating that LSDV is enveloped virus and agree with that recorded by (Ploweright and Ferris, 1959). Isolation of LSDV from cattle previously vaccinated with live attenuated SPV vaccine may be explained by failure in the vaccine application, denaturation during transportation, storage or after reconstitution. Complete identical neutralization of isolated LSDV strain by using both SPV and LSDV antisera suggesting high degree of homology between LSDV and SPV and minimizing the speculation regarding strain variation between SPV and LSDV (Table 6). This result is in agreement with findings of (Davies and Atema, 1978; Davis, 1982; Abraham and Zissman, 1991) who reported that Kenyan sheep and goat pox virus was very closely related to LSDV and showed complete cross reaction. In addition, Fahmy, (2000) reported that cattle vaccinated with SPV vaccine in the field were $85.7 \%$ immune reacted by skin test. It is of interest to show that cattle vaccinated with live attenuated SPV vaccine under experimental condition can withstand natural field infection with LSDV indicating high degree of homology between LSDV and SPV. The isolated strain needs further molecular investigation to confirm this result. Finally, it was possible to use an inactivated vaccine prepared from locally isolated virus strain supplemented with good adjuvant to overcome the problem of vaccination failure probably due to denaturation of vaccinal material. In additional, application of strict precaution is necessary to ensure that the animal received sufficient dose of the vaccine.

\section{References}

Abraham, A. and Zissman, A. (1991): Isolation of lumpy skin disease virus from cattle in Israel. Israel J. Vet. Med., 46 (1): 20-23.

Ali, A. A., Esmat, M.; Attia, H. and Selim, A. (1990):

Clinical and pathological studies on lumpy skin disease in lower Egypt. $4^{\text {th }}$ Sci. Cong. Fac. Vet. Med. Assiut Univ., Egypt. pp. 892-899.

Anderwes, C. H. and Horstmann (1949): The susceptibility of viruses to ethyl ether. J. Gen. Micobiol., 3. 290-297.

Barnard, B. J. H.; Munz. E. and Dumbell, K. (1994): Lumpy skin disease. Infectious and diseases of live stock with special reference to South Africa. Cape Town. Oxford University, Press, pp. 604-612.

Benton,W. J.; Cover, M. S.; Roseuler, J. K.and Lake, R. S. (1967): Physico chemical properties of infectious bursal agent. Avian Dis., 11: 438-445.

Carn, V. M. and Kitching, R. P. (1995): An investigation of possible routes of transmission of lumpy skin disease virus (Neethling). Epidem. Infect., 114 (1): 219-226.

Charles, H. C. and Stuart, H. O.(1947): The pH stability of the virus of infectious bronchitis of chickens. Cornal. Vet., 37 (2): 99-103.

Davies, F. G. (1981): Lumpy skin disease in virus diseases of food animals, Disease Monogtaphs. Vo 2 ed Ep.j Gibbs. Academic press London, pp. 751-764.

Davies, F. G.(1982): Observation of Epidemiology of lumpy skin disease in Kenya. J. Hyg. Canb., 88: 95-102.

Davies, F. G. (1991): LSD of cattle a growing problem in Africa and Near East. World Anim. Rev., 68 (3): 37-42.

Davies, F. G. and Atema. G. (1978): The antibody response in sheep to infection with a Kenyan sheep and goat pox virus. J. Comp. Path., 88: 205-210.

Fahmy, H. A. (2000): Studies on intradermal allergic skin test of lumpy skin disease virus in cattle. Ph.D. Thesis (Virology). Fac. Vet. Med. Cairo Univ., Egypt.

Fayed, A. A.; Saber, M. S.; Mousa, A. A. and Reda, I. M. (1988): Hours annual report on the scientific progress of PI480 project, Grant No T.G- EG 216 project No.

Haig, D. A. (1957): Lumpy skin disease. Bull. Epizot. Dis. Afr., 5: 421-430.

Hassan, H. B.; Ebied, M. H.; El-Din, A.; El-Attar, H.; Mousa, Sh.; Yassin, S. and El-Kanawaty, Z. (1992): Some virological, serological and hematological studies on LSD in Egypt. Proc. $5^{\text {th }}$ Sci. Cong. Fac. Vet. Med. Assiut Univ., Egypt. 8-10:61-65.

House, A. J., Wilson, T. M.; El-Nakashly, S.; karim, I. A. ; El-Danaf, N.; Mousa, A. N. and Ayoub, N. N. (1990): The isolation of lumpy skin disease virus and bovine herpes virus from cattle in Egypt. J. Vet. Diagn. Invest., 2: 111115 .

Irons, P. C.; Tuppurainen, E. S. and Venter, E. H. (2005): Excretion of lumpy skin disease virus in bull semen. Theriogenol., 63: 1290- 1297.

Madbouly, H. M.; Ismail, M. R. and Tamam, S. M. (1996): Role of infectious laryngotracheitis virus vaccine in spreading of ILT disease among and between layer and broiler birds. BS.Vet Med. Res., (6): 27-42.

Michael, A.; Soliman, S. M.; Saber., M. S; Fayed, A. and Mousa, A. A. (1994): Vaccination of cattle against LSD with tissue culture sheep pox vaccine Med. Assiut, Egypt. 536-541. 
Pandey, R. and Singh, I. P. (1970): Cytopathogenicity and neutralization of sheep pox virus in primary cell culture of ovine and caprine origin. Ind. Pathol. Bact., 13: 6-11.

Plowright, W. and Ferris, R. D. (1959): Ether sensitivity of some mammalian pox virus. Virology. 357.

Reed, L. Y. and Muench, H. (1938): A simple methods of estimating fifty percent end points. Am. J. Vet. Res., 18: 618-624.

Thomas, A. D. and Mare. G. V. E. (1945): Knopvelsiekate. J.S. Afr. Vet. Med. Assoc., 16: 36- 43.

Woods, J. A. (1988): Lumpy skin disease. A review Trop. Anim. Hlth. Prod., 20: 11-17.

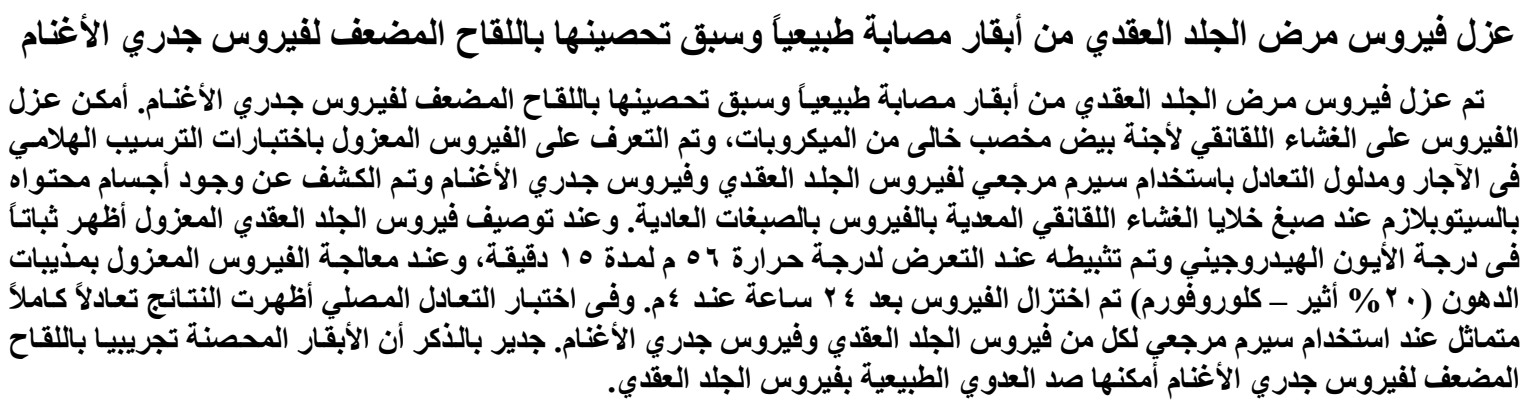

